Journal of Siberian Federal University. Humanities \& Social Sciences 9 (2017 10) 1368-1381

\title{
The Russian European: the Phenomenon of Mikhail Shishkin
}

\author{
Galina P. Mikhailova* \\ Vilnius University \\ 3 Universiteto Str., LT-01513, Vilnius, Lithuania
}

Received 10.01.2017, received in revised form 15.08.2017, accepted 25.08.2017

The concept of the "Russian European" and the way it is understood is linked with the definition of Europe as an idea and an identity. Perception of Europe as a symbol and a cradle of spiritual, ethical and legal values characterize mentality in Russia as well as in Central and Eastern Europe. This allows to compare models of behaviour and ways of thinking as well as crisis periods of selfidentification of such "Europeans" as Shishkin and Cz. Milosz who both encountered Western Europe. Trying to preserve Russian national identity while being in Switzerland, Shishkin turned to a discursive position, which might be described as preservation of "heritage of cultural forms" and wrote a literary and historical guidebook "Russian Switzerland" and an essay collection "MontreuxMissolunghi-Astapovo, in the Steps of Byron and Tolstoy". As far as publicism is concerned the "recipe" of changing and revival of Russia proposed by Shishkin is traditional enough for Russian westernists: "Information. Education. Mitigation of customs. Freedom of speech". The article emphasizes that the "recipe" is based on philosophy of human dialogical nature, and it is closely related with the idea of freedom and with ethics of dialogical personalism rooted in categories of responsibility, commitment, sympathy and compassion. It is important that compassion is the nerve of Shishkin's big and small prose. Asserting dialogical relationship with Western civilization and culture and being convinced of impossibility of "dialogue with the state", Shishkin as Nabokov before him takes out civil service of the writer beyond belles-lettres but reserves his right for critical reflection and for comment in genre of publicism. Shishkin's desire to identify himself with cosmopolitical cultural elite is obvious. For this very reason his judgements of "another Russia" and his own affiliation with it implies most of all cultural opposition; his position is about individual self-determination of an artist, principle of civil particularism harmonically combined with cosmopolitism and "smart nationalism".

Keywords: European ideas, philosophy of dialogue, ethical values national identity, self-identification.

DOI: 10.17516/1997-1370-0142.

Research area: philology.

The topic designated in the title of the aricle requires a brief preamble concerning the content aspects of the concepts Europe and the "Russian European". Gerard Delanty, who outlined six historically existing definitions of
Europe, wrote: "Europe is more than a region and polity, it is also an idea and an identity" (Delanty, 1995: 3). Leaving aside the notion of Europe as a geo-political reality important for Russia at various stages of its history, let us

(C) Siberian Federal University. All rights reserved

* Corresponding author E-mail address: nkovtun@mail.ru 
concentrate on the definitions of Europe related to the issue of a person's belonging to a certain socio-political, cultural-historical and value narrative, that is, Europe as an idea and identity. It seems that the notion and understanding of the "Russian European" for three centuries have not been connected, first of all, with these ideas about Europe. This means that the concept of the "Russian European" included the following content: the desire to present Russia as a peripheral but equitable version of a cultural and civilized Europe (as opposed to the Western European mythologization of Christian Russia as an exotic country of barbarism and chaos that has nothing in common with Europe); the existential need to affirm an unevident European self-identification (poorly confirmed geographically, historically and religiously); a certain missionary message - to be a personal example of an educated enlightened person proving the European mentality.

Calling the famous contemporary writer Mikhail Shishkin a "Russian European", we, like it or not, introduce him into the framework of the above intentions, into a number of typical figures of Russian Europeanism recorded by a considerable number of researchers, beginning with Gleb Struve (Struve, 1950) and ending with, for example, Tomas Venclova (Venclova, 2004). Herewith, it is necessary to take into account the situation that has developed in the space generating modern Russian literature. This refers to the movement of its creators to a variety of geographical loci. According to the reference book of Sergei Chuprinin, a considerable number of contemporary Russian writers live and work in European countries (Chuprinin, 2008: 746-774).

Shishkin, who has been residing in Switzerland for more than twenty years and creating texts in European spaces, is not an exception. Thus, the position of the modern "Russian European" includes in the case of Shishkin a sign of territorial location that does not cancel the quality of the "enlightened minority in Russia" in the writer's self-consiousness, which Vladimir Kantor called feeling "oneself a European not only in Europe but also in the homecountry" (Kantor, 2016: 83). We will define this feeling as a sense of responsibility for the Russian culture, worries and care for it, which can be observed in Shishkin's interviews, conversations and speeches, as well as the literary and historical guidebook "Russian Switzerland" (1999), an essay collection "MontreuxMissolunghi-Astapovo, in the Steps of Byron and Tolstoy. Literary walk from Lake Geneva to the Bernese Alps" (2002). However, one should take into account that since the beginning of 2013 the situation has changed somehow. Let us consider two tendencies, one of which has an ethicalpolitical dimension, and the other is purely artistic. The first is Shishkin's principal leaving of the Russian literary establishment: in February 2013, Shishkin refused to represent Russia at the International Book Fair in the US, writing about it in an "open letter" addressed to the Federal Agency for Press and Mass Communications of the Russian Federation and Directorate of the Fund "Presidential Centre of B.N. Yeltsin"; in November of the same year, at the Moscow International Non-fiction Book Fair, Shishkin was already representing Switzerland. The second is the writer's moving away from large novel forms (the last novel, "The Letterman", was published in 2010), and the active transfer to the translation segment of the literary field (the translation of the story "The Walk" (Progulka) by the classic writer of the Swiss literature Robert Walser and the accompanying translation of the essay "Valzer i Tomcak" ("Walser and Tomcak")). Shishkin argues his "moving away" and "transition" psychologically: working with small genres frees time for personal life (Shishkin, 2016b), and rhetorically (using the ironic entyma): “... if suddenly I no longer have a novel, then you know 
who is the one to blame. Translators are guilty" (Shishkin, 2013b) ${ }^{1}$.

In our opinion, the latter in Shishkin's case is not so much due to the author's vanity, but to the general attitude of the "Russian European" who is close to foreign cultures and for whom Russian culture was and should remain a part of European culture. The former belonging of the Russian literature to the European cultural and civilizational space is indisputable for Shishkin, the situation with the literature of the second half of the $20^{\text {th }}$ century and contemporary literature is problematic. Shishkin's desire to "combine all the verbal achievements of the Western literature, its technical sophistication with Russian love for Akaky Akakievich" (Shiskin, 2005) shows not only the writer's reflection regarding the aesthetic resources of the Russian language, but is a manifestation of the orientation of the "Russian European" to Europe as a cultural centre. This, in principle, is another acknowledgment that "previously Russia did not belong to Europe" (Uspensky, 2012: 182).

But in the intent of Shishkin there is some shade of culture bearing with respect to Europe. Let us take as an axiom the judgment of the prominent modern sociologist and philosopher Zygmunt Bauman, who defines the modern era (mainly European) as "liquid modernity" characterized by cultural unconsciousness, destroyed illusions, uncertainty, insecurity of the future, "the tendency towards 'adiaphorization"”2. In a similar world wittyly labeled by Bauman as "The World of TINA", the "classic Russian novel written today" as a novel about love, "overcoming of death, which is the boundary between people", God's eternal pity for Nineveh (Shishkin, 2005, my italics - G.M.), acts as a sign system representing, fixing and transmitting the information about universal human values.

The idea of Europe (especially Switzerland) as a symbol and cradle of spiritual, ethical and legal values is a feeling inherent in the mentality of Central and Eastern Europe, and, at the same time, a feeling typical for Russia. In the context of this "feeling", one can refer both to the wellknown opinions of the representative of the Golden Age Petr Chaadaev about Europe as a project of moral order and a configuration of ideas and values, as well as to the liberal ideas of the representative of the Silver Age Vladimir Veidle, who included Russia in Europe "as its integral part" and believed that at a certain historical moment, by the power of the Bolsheviks, Russia having committed violence against itself, expelled itself from the European cultural space (Sizemskaia, 2015). Let us compare these ideas with one of Shishkin's last speeches at the First International Literary Festival litfestodessa.com in early October 2015: “... It is not me who is the enemy of the people, but those people who are in the Kremlin. They are destroying before our very eyes what has been created with such difficulty for the last 20 years and are leading the country to some kind of apocalypse. $<$... $>$ a hundred years ago Russia of that time with its lands and selfgovernment was so much closer to European values, was so much more developed than the country that we have now" (Shiskin, Zhadan, 2015).

If we talk about the value hierarchy presented by the European civilization space, Shishkin in "the European discourse of personality" (N. Plotnikov) is interested in the idea of such an abstract human feature as "to be a subject of freedom", a subject of their actions, which makes the personality responsible, but this responsibility, in his opinion, is eliminated from the self-consiousness of his countrymen. Another important personal construct of Shishkin is the model of independent and unique creative individual character (Plotnikov, 2008), which does not include the interests of the reader and the publisher. Shiskin considers "writing without 
compromises" to be the demonstration of the Russian literature tradition: the creative activity of a writer does not pursue any commercial goals (Shishkin, 2016b). This combination of two non-conformist modalities: the opportunity to do (freedom) and the opportunity not to do (independence) seems to form the code of souverenity (autonomy) of the writer Shishkin, which is contrary to the code of submission (patience). In the dialogue with the writer Boris Akunin patience was called "the art of survival in Russia" that had been developing through several generations: "People still consider themselves weak and helpless in front of the all-mighty officer who only cares about his own profit. The only thing left for them is to be patient and die. The psycology of slaves is still ruling the country, there is still no system of public government in Russia, which is the basis of the Western civilization" (Shishkin, Akunin, 2013).

In this dialogue, postulating autonomy and individuality as the most acceptable models of personal behaviour, Shishkin and Akunin are building the opposition "We" and "They" on different grounds within the "Russian people" phenomenon. Akunin opposes the intelligentsia and the people. Shishkin opposes the intelligentsia-Westerners and the intelligentsiaRussophiles. On the one hand, in the binary judgment of Akunin there is nothing exclusively national. If we handle the ideas about ethnosymbolism of Anthony D. Smith, then "reciprocal relationship" and "internal conflicts" "between elites and non-elites" are typical for any national society: "The vision of the nation proposed by one or another elite may or may not strike a chord among members of the non-elites, eliciting a weak or a strong response; alternatively, the latter may reject or amend it, preferring another project offered by a rival elite" (Smith 2009, 116). On the other hand, Akunin's binary-oppositional thoughts fit into the traditional discourse of the
Russian intelligentsia, including the creative one: "Through the concept of personality, the intelligentsia defined itself in relation to the people and power cultivating its creative superiority over them and, at the same time, demanding from them the recognition of its own uniqueness. If it was denied such recognition, it was experiencing a crisis of self-awareness" (Plotnikov, 2008).

Shishkin's reasoning ${ }^{4}$, later clothed in the formula of the "eternal civil war" within the Russian literary space and supported by references to criticism of his novels in "Literaturnaya gazeta" and "Novyi mir" (Shishkin, 2016b) ${ }^{5}$, is also not an exclusive feature of the Russian socio-cultural process. As A. Smith notes, "Inter-elite conflicts have been the most visible in the historical record, notably between rival factions of the intellectuals and professionals" (Smith, 2009: 116).

Therefore, it would be relevant to consider Shishkin's solution of the problem of personal identity in line with A. Smith's judgments about the nation and national identity. Protecting his national identity as a Russian person, in Switzerland Shishkin took such a discursive position that supposed turning to the "heritage of cultural forms" (Smith, 2009: 30) as the foundation of the nation in the form of "collective cultural identities"(Smith, 2009: 18). In a certain long enough period of time, the complex cultural and historical dimensions of the national identity, in relation to which the individual acts as an abstract unit, played the role of important value benchmarks for Shishkin: "I left Russia for another world and realized that I was blind, because when you live at home, you see all the invisible threads that bind the world. You know what thread can be pulled, and which one should not be touched. And here I understand that the world is connected by the threads, which I do not see. It took time to get a better look, to understand how this life functions <...> I lived in the same space as Chekhov, Bunin, somehow we were 
all together, but here I am all alone" (Shishkin, 2016a. My italics - G.M.).

The state described by Shishkin can be called the crisis of self-identification. It (even by the fact of being in the same cultural and civilized space, Switzerland) can be compared with the feelings described by Czeslaw Milosz in his introduction to his book "Rodzinna Europa" published in Paris in 1959 and received in the English translation a compelling but not very precise clarification: "Native Realm: A Search for SelfDefinition": "In Western Europe, however, it is enough to have come from the largely untraveled territories in the East or North to be regarded as a visitor from Septentrion, about which only one thing is known: it is cold. ...I felt both a native and a foreigner. Undoubtedly I could call Europe my home, but it was a home that refused to acknowledge itself as a whole; instead, as if on the strenght of some self-imposed taboro, it classfied its population into two categories: members of the family (quarrelsone but respectable) and poor relation $<\ldots>$ How many times I had remained silent because, having come from those foggy expanses that books, even textbooks, rarely provide information about (or, if they do, provide false), I would have had to start from a scratch! $<\ldots>$ The first germ of this book, then, was the desire to bring Europe closer to Europeans" (Milosz, 1981: 2). The English subtitle of Milosz's book stems both from the intention of the work and from its text: Milosz, on the example of his personal biography, talks not so much about personal self-determination, about the artist's self-determination, but about the existential experience of the collective figure of an Eastern European intellectual who crossed the border between the European East and the European West. The dramatic nature of the national and cultural self-identification of Eastern Europeans was complicated by the fact that small provincial cultures (for example, Polish or Lithuanian), due to various historical reasons, did not introduce themselves into the European context. Such, according to Milosz's observations, was the selfawareness of the Eastern European intelligentsia which moved from Eastern Europe to Paris.

From this point of view, the "confusion in front of the face of Europe" (S. Milosz) of the Russian writer Shishkin was, in our opinion, purely personal: the West acted as a frustrator on the way to the attainment of the state of comfort human and creative. Another thing is the rescue found by Shishkin in the "colonization" of the space of the Switzerland by the names of its permanent or temporary inhabitants: Karamzin, Bunin, Rakhmaninov, Gorky, Dostoyevsky, Nabokov and others, that is, writing the abovementioned "Russian Switzerland" and essay collection "Montreux- Missolunghi-Astapovo, in the Steps of Byron and Tolstoy": "The book that I wrote "Russian Switzerland: literary and historical guidebook" helped me a lot: <...> I built my cultural colony, wrote this book, went in search of traces of all my "relatives" - Tolstoy, Dostoyevsky - studied where they were, what they wrote about Switzerland. I found them all and understood that now I can live here" (Shishkin, 2016a). This was possible due to the realization that Russian culture (the culture of the two preceding centuries) is not an antipode of European culture.

Is the "Russian European" Shishkin a patriot, after he said in the summer interview in 2016 "One of my feet has always been in Russia. Only now because of recent events ${ }^{6} \mathrm{I}$ do not want to go there. But before that, one foot was always there, and the other was wandering around the world somewhere. Thank God, I lived and worked in America, in Germany. I think all people need to travel around the world, especially writers. Because when you leave, you realize what you've lost. First of all, you lose language $<\ldots>$ There were two moments in Russia when 
there was a hope that something would change: in 1917 and during perestroika. And it seemed ... that ... people ... would make a step into the normal human side - let us call it democracy, civilization, whatever. But each time there is so much blood that the country slips and again falls into this bloody bath. I am afraid that there would not be a third chance ... no one would believe that democracy can exist in Russia. I will not believe it anymore, unfortunately!” (Shishkin, 2016a).

Answering this question, firstly, let us note that the writer (perhaps, recoding the meaning of the well-known lines by Sergei Esenin "I stayed in the past with one foot, / Aspiring to catch up with the steel army, / I slip and fall with another", full of the same patriotic reflection) describes the being of the modern man. As Homi K. Bhabha writes, “...in the fin de siècle, we find ourselves in the moment of transit where space and time cross to produce complex figures of difference and identity, past and present, inside and outside, inclusion and exclusion. For there is a sense of disorientation, a disturbance of direction, in the 'beyond': an exploratory, restless movement caught so well in the French rendition of the words au-delà - here and there, on all sides, ... hither and thither, back and forth" (Bhabha, 1994, 1).

Secondly, let us define the concept of "patriotism" and how Shishkin understands it. Patriotism in the classical (Roman) sense of the word is, above all, civil (self) consciousness. Here is what Shishkin says in connection with this in his dialogue with Akunin: "'Patriotism' is a tested way of keeping slaves in obedience. And the government will do everything to prevent people from feeling free citizens aware of their responsibility for their land, for their country. $<\ldots>$ Civil society cannot exist without an initiative from below, but this is exactly what is being stopped by the authorities in Russia by all possible and impossible ways" (Shishkin,
Akunin, 2013). The key words in this statement are freedom and responsibility. The ideas of the heterogeneity of the political correctness standards and the tolerance category, the invariability of the preserved Orthodox truth in time and space and, most importantly, the idea of Russia's self-sufficiency as an "island surrounded by the ocean of enemies" (Shishkin, Akunin, 2013), according to Shishkin, lie at the base of Russian "slave psychology" and modern state patriotism. In this regard, Russian etatistic patriotism is joined with conservative nationalism, that is, with nationalism of land and blood. While civil patriotism is a nurtured thing. "There is only one recipe for a Russian miracle" (for change, for revival), according to Shishkin, and it is quite traditional: "Information. Education. Mitigation of customs. Free word" (Shishkin, Akunin, 2013).

If we think about Shishkin's idea of enlightenment in the traditional context for Russian Westerners, the writer probably understands the well-known thing - overcoming the separation from Western civilizational systems in which the inviolability of liberal and democratic values is approved (antiauthoritarianism, the doctrine of human rights, minority rights, tolerance, respect to the other) and the idea that they are irreplaceable. And, of course, we are talking about common cultural references (Raphael's paintings, Shakespeare's tragedies, Bach's symphonies, etc.) as cultural indicators of identity, European identity and selfunderstanding. Without referring to the wellknown (to the cultural capital - Dante, German romanticism, Goethe, English metaphysical poetry, which became the foundation of the creative life of Russian Europeans Mandelstam, Tsvetaeva, Bulgakov, Brodskii), let us refer to the Lithuanian context of such enlightenment, which can be regarded as a means of disclosing the "secrets of physics and metaphysics of Europe" 
and as "a way of accumulating national cultural capital". This was discussed by one of the most authoritative modern Lithuanian writers and translators Sigitas Geda, who discovered the "cultural foundations of Europe" through reading and translating German, Italian (including Dante) and French (including the Old French) classics into Lithuanian (Geda, 2008).

Repeatedly proclaimed Shishkin's own writing mission is the return of modern Russian literature to the bosom of the world literature. It is about Russian literature of universal sound and universal content. Apparently, prose with a certain socio-political content and recipient is excluded from the process of return: "We have sat too long behind the barbed wire and for generations have been isolated from the rest of the world. And now there is no more barbed wire, but only Russians reading Russian writers. It's time to write in Russian clearly about common understandable things and return to the world literature" (Shishkin, 2011. My italics - G.M.). Such a position, of course, has nothing to do with the "Russian civilizational complex of the "abduction of Europe" (Tsymbursky, 1997), which identifies the historical existence of Russia with its manifestation in European geopolitics. Does it contain any echo of the well-known idea of "messengerism" of the first Russian emigration? In general, no, because Shishkin transforms the task of restoring Russian culture in "European rights" by the idea of forming the modern Russian one without its return (even symbolic) to the mother's womb. In this sense, his reference to the thought of the high-esteemed writer and essayist Aleksandr Goldshtein that "the idea of "Russia-centrism"” in literature has already passed, is indicative and the Russian diaspora in any country can create its own culture" (Shishkin, 2014). Nevertheless, the image of Shishkin as a modern culture bearer - an immigrant from Russia, contains the hypostasis of the "keeper" of the already existing Russian culture. It manifests itself in the need to "save" the "substance of Russian literature" from the indestructible incrustation of ideology and politicization in the Russian space (Shishkin, 2006, 2010).

As mentioned above, the union of education and information, the exchange of which is the grain of the communication process, is not less important for the "European" Shishkin. Thus, the basis of Shishkin's "tetralogical imperative" "Information. Education. Mitigation of morals. The free word" is the philosophy of the dialogical nature of human existence (the concepts of Mikhail Bakhtin, Martin Buber, Emmanuel Levinas) closely related to the idea of freedom ("in this world I can be free to the extent that You recognize my freedom") and the ethics of dialogic personalism based on categories of responsibility, commitment and sympathy (Levinas, 1994: 100-104). Let us note that pity (sympathy, compassion) is the nerve of Shishkin's big and small prose. Answering the question of the Estonian journalist why he does not describe the appearance of protagonists in his novels, Shishkin answers: "Because the appearance is what divides us, prevents us from converging, understanding, makes us different and alien. And if the appearence is removed, it suddenly turns out that inside people are incredibly similar. Everyone wants human warmth, everyone wants to cuddle up to each other, to sympathize with each other. My novels are about mutual understanding and human rapprochement. Therefore, in the first place I remove appearance from the characters and give them an opportunity to get closer to each other" (Shishkin, 2016a). Such an artistic strategy certainly contributes to the "mitigation of customs" Shishkin writes about, and, therefore, contributes to the result he has indicated - the desired reorganization of Russian society on the principles of Western European civilization ${ }^{7}$. In the framework of the Dialogue of 
Cultures concept, which author Vladimir Bibler interprets the ideas of Bakhtin in the context of cultural being ${ }^{8}$, Shishkin approves dialogical relations with the Western civilization and culture, critically interpreting the socio-political and artistic practice of his motherland. Being convinced of the impossibility of the "dialogue with the state" (Shishkin, Zhadan, 2015) ${ }^{9}$ after the failure of public speeches of the Russian nonsystem opposition in the winter of 2011-2012 (the so-called "snow-white revolution"), Shishkin firmly determines his position in the field of literature. Following his famous Swiss compatriot Vladimir Nabokov, he takes the writer's civil service beyond the limits of the creative word, but reserves the right of critical reflection and comments in the genre of journalism: "I'm sure there should never be modern politics in the novel. $<\ldots>$ Journalists should deal with it. Prose, real art is about something else. About deeper and more important things. About what will be important even after 20 and 30 years... But besides being a writer, I am also a normal person, a citizen of my country, who believes that it is not me who is the enemy of the people, but those people who are in the Kremlin. They are destroying before our very eyes what had been created with such difficulty for the last 20 years and are leading the country to some kind of apocalypse" (Shishkin, Zhadan, 2015). If one thinks in terms of categories of liberal Westerners, Shishkin's position represents attachment to his homeland with a great sense of moral responsibility for it and alienation from certain essential aspects of political existence and socio-cultural development of Russia.

This is a model of the existential situation and ethical programme of Russian political emigrants: to emigrate from the country in order to be able to speak the truth out and stay true to their principles and conscience ${ }^{10}$.

Equally often in his public speeches, Shishkin (in the spirit of binary logic) refers to opposing two types of morals and two standards of behaviour. For example, in the interview in 2011: "... there is only such a choice: either for the sake of preserving your dignity you do not compromise and sacrifice your beloved ones, favourite occupation, life, go out with a poster to the Red Square, sit in jail, end your life, simply remain unemployed on the street, or for the sake of your family, children, beloved ones, you are ready to sacrifice your dignity and compromise with the regime, boss, era, neighbour" (Shishkin, 2011) or in dialogue with B. Akunin: “...Russia is a wonderful country for scoundrels, and for those who battle scoundrels (The latter do much less well, though). This empire is not designed for "normal" life. If, by your nature, you are neither a hero nor a scoundrel, and you merely want to live your life with dignity, working honestly for your family's bread, you still have no choice: every day pushes you toward one or the other. You don't want to be a scoundrel like the rest? Then become a fighter, tragically ready to sacrifice everything, even your family, for the sake of the fight. You don't want to be a hero and rot in prison, or be beaten to death in the lobby of your building? Then line up with the scoundrels" (Shishkin, Akunin, 2013). The dicision that Shishkin has taken in terms of dilemma between "sacrificial struggle" and "sacrificial compromise" connected with the "basis of European sense of the world" (Kantor, 2007): the idea of privacy and the role of literature in the development and consolidation of privacy.

On the axis "Nikolai Karamzin - Sergey Nechayev" built in his travelogues (in which the first one, as Shishkin believes, in his notes on Switzerland, set "the vector of moving to the priority of privacy values, which is new to the totalitarian system", and the second one found in Switzerland "a paradise place" for the "development of the Russian terror" (Shishkin, 1998)), Shishkin moves in the Karamzin 
direction: towards Nabokov ${ }^{12}$ and Brodskiii ${ }^{13}$ : "All his (Nabokov's) life is the salvation of his family, his language and manuscripts-cards from ideologies and regimes". He gives his protagonists a place where one can live and die simply from private life, without the help of tyrants. He gives to himself the country of "happy doormen"” (Shishkin, 1998). For comparison, the same idea of privacy is an important meaning-building motif of the "Nobel Lecture" of the Russian European Joseph Brodskii: "One of literature's merits is precisely that it helps a person to make the time of his existence more specific, to distinguish himself from the crowd of his predecessors as well as his like numbers, to avoid tautology - that is, the fate otherwise known by the honorific term, 'victim of history"' (Brodskii, 1987).

Shishkin, who has both the Soviet and postSoviet past, behind his back, felt the cultural, moral and socio-political life of the Russian man not as a theoretical problem, but as an existential drama. From this point of view, the journalistic elocutive specificity of Shishkin's certain statements about Russia ("a place not adapted for life", where the "process of extinction of a person as a species" is obvious and "living is dangerous for health" (Shishkin, Akunin, 2013)) can be interpreted as an expression of the decay of what Petr Chaadaev called "the physiology of the European man” (Chaadaev, 1989: 45), implying European values that are a part of the flesh and blood of the man of Europe.

Let us summarize the above.

Since the material for our discussions was mainly Shishkin's social and political writing, in terms of the problem of self-determination of the "Russian European" we can turn to the theses of the imagologists that in the modern multicultural media society, it is not identity that is important, but identification, that is not what you are, but what you have chosen to identify yourself with (Leerssen, 2007).
Shishkin's desire to identify himself with the cosmopolitan cultural elite is obvious. In this regard his preface to the Russian translation of the book of memoirs of the Swiss writer Ilma Rakusa "Mehr Meer" ("More Sea") is quite typical, in which the main emphasis is on the writer's affiliation to "the new Europe without borders interwoven from languages and cultures", and the genesis of her personality and creativity is "the whole of European culture" (Shishkin, 2015). Therefore, Shishkin's judgments about "the other Russia" and his belonging to it (Shishkin, 2016) are least connected, in our opinion, with political dissidence and imply, first of all, cultural opposition: "The "other" Russia is not a geographical concept. It exists where there are "other" Russians. And so it was that over the course of several generations, the "other" Russia, the Russia of poets and writers, the Russia of culture, destroyed in the Soviet Union, was preserved underground and in emigration" (Shishkin, 2013a).

Shishkin's publicistic constructions are rooted in his personal experience. His position is the position of individual selfdetermination of a person, the principle of civic particularism harmoniously combined with "smart nationalism". The contemporary "Russian European" represented by Shishkin is true to his language as a means of artistic expression, he loves his homeland, but he likes the common European space in which, above all, it is comfortable to live. The natural sympathy for the European order, the variety of languages of culture, the countries you like, do not conflict with the feeling of patriotism. The concepts of the enlightened European cosmopolitan and European patriot are not hostile to each other. According to the experienced Lithuanian European, Tomas Venclova, "the cosmopolitan is a smart nationalist, and the nationalist-noncosmopolitan is an unintelligent nationalist" 
(Venclova, 2014). For Shishkin as a European patriot patriotism is not a territorial concept and is opposed to nationalism with its ideas of cultural isolationism and the mentality of intolerance. In this regard, according to the writer, it can co-exist with the totalitarian ideology and its mutations.

1 Shishkin is known for his traumaic perception of "deficiency" of translations of his novel into other languages that he metaphorically explained as: "The original text is the "Titanik", the translation is an iceberg. All the bottom of the world literature is full of such remains of the Titanic" (Shishkin, 2016).

2 "Adiaphorization" is "the exemption of a considerable part of human action from moral judgement and, indeed, moral significance" (Bauman, 1996: 32).

3 TINA - abbreviation of There Is No Alternative (Bauman, 2014; Bauman, Donskis, 2016).

$4 \quad$ “... in Russia, there are two peoples coexisting with each other, speaking Russian, but mentally opposed to each other. One head is stuffed with European education, liberal ideas and notions that Russia belongs to a universal civilization. This head does not want to live under the patriarchal dictatorship, it demands freedom, rights and respect for its dignity. Another head has its own, still medieval image of the world: holy Russia is an island surrounded by an ocean of enemies, and only the Father in the Kremlin can save the country. These are We and They" (Shishkin, Akunin, 2013).

5 Criticism of Mariia Remizova is typical in relation to the author of the novel "Vziatie Izmaila" ("The Capture of Izmail") as to one of the modern Russian writers who believes that "the full-fledged existence of Russian culture ... can be realized only if it is unified with samples and stereotypes peculiar to the West European cultural space". These are frank claims to the writer - "westerner". The memorable struggle with "bourgeois cosmopolitanism" is also reminiscent of the final of the article by Remizova, which ends with the comparison of the writer with a "bewitched rat" following the "path of decline", and a rhetorical question: "Should Russian literature, which has reached the most significant peaks of world culture, necessarily adjust to the obviously temporary, although in demand, world standard?" (Remizova, 2000).

6 The reason for the self-characterization of Shishkin as a representative of "the other Russia" in the statements of 2015-2016 were the actions using posters and banners with portraits of "national traitors" in Moscow in the spring of 2014: "The last straw for me was a picture of my Moscow, my New Arbat, my store "House of Books" with a huge poster. There was a banner with faces of people whom I respect very much, whom I consider to be my friends. And Grisha Chkhartishvili (Boris Akunin. - G.M.) and Liusia Ulitckaia are "national traitors". <.. > If you do not live by the rules, if you say something, you will have problems. And I acutely felt that I do not want to live anymore according to these rules. That this is no longer my city, not my Novy Arbat, not my bookshop. I do not want to come there any more. Because I, of course, also feel as a national traitor, a national enemy" (Shishkin, Zhadan, 2015).

7 One of the components of the Shishkin's "imperative" - the "mitigation of customs" (l'adoucissement des murs), is included in the primary ethical definition of the civilization, which in Western culture and philosophy is associated with the manuscript Marquis de Mirabeau of the mid-18th century. "L'Amy des Femmes, ou Traité de la Civilization"; "Frend of Women, or Treatise of Civilization" (Nef, 1958: 79). The very concept of civilization in the French language is etymologically related to one of the meanings of the verb civiliser - to educate.

8 “...culture is where there are two (at least) cultures, $<\ldots>$ self-conciousness of culture is the form of its existence on the border with another culture" (Bibler, 1991).

9 Shishkin devoted his essay "Poet and Czar. Two Russias From Pushkin to Putin: the sad tale of democracy in Russia" to the constantly reviving Russian collision - antagonistic intersection of the field of power and the field of literature. He writes: "This was the ultimate question of Russian literature, to which every generation of Russian writers painfully sought an answer: should the poet be with the czar, or against him?" (Shishkin, 2013a).

10 From the point of view of modern emigrantology, Shishkin, constantly reminding of the personal (family) reasons for his relocation to Switzerland, falls under the definition of "expatriate" - a person who left the country voluntarily, who is not an exile and does not consider himself so.

11 The definitions of the two types of "heroic behaviour", proposed by the well-known psychologist Vladimir Lefebvre (Lefebvre, 2002), are applicable to Shishkin's dichotomy conditionally, since the "sacrificial compromise" in his interpretation is reduced to baseness.

12 This is the title of the chapter in Shishkin's book "Russian Switzerland".

13 Shishkin's reads the life of the poet Brodskii as "a textbook case" (Shishkin, 2013a).

\section{References}

Bauman, Z. (1996). From Pilgrim to Tourist, or a Short History of Identity, In Questions of Cultural Identity. Ed. by: Stuart Hall \& Paul du Gay, 18-36. Available at http://www.hu.mtu.edu/ jdslack/ readings/CSReadings/Bauman_From_Pilgrim_to_Tourist.pdf

Bauman, Z. (2014). A world without alternatives, In Eutopia Magazine, 8 Novembre. Available at: http://www.theglobaldispatches.com/articles/tina-a-world-without-alternatives (accessed 12 October 2014)

Bauman, Z., Donskis, L. (2016). Liquid Evil. Cambridge Polity Press, 192 p. 
Bhabha, Homi K. (1994). The Location of culture. London, Routledge, 285 p. Available at: http:// tarjomaan.com/images/docs/files/000006/nf00006720-1.pdf.

Bibler, V.S. (1991). Mikhail Mikhailovich Bakhtin, ili Poetika kul'tury [Mikhail Mikhailovich Bakhtin, or the Poetics of Culture]. Moscow, Progress, 176 p. Available at: http://philologos.narod.ru/ bakhtin/bibler_dial.htm

Brodskii, J. (1987). Nobel Lecture. Available at: http://www.nobelprize.org/nobel_prizes/ literature/laureates/1987/brodsky-lecture.html (accessed 18 December 2016).

Chaadaev, P. (1989). Stat'i i pis'ma [Articles and Letters]. Moscow, Sovremennik, 623 p.

Chuprinin, S. (2008). Zarubezh'e: russkaia literatura segodnia [Abroad: Russian literature today]. Moscow, Vremja, $782 \mathrm{p}$.

Delanty, G. (1995). Inventing Europe: Idea, Identity, Reality. Basingstoke, Macmillan Press LTD, 187 p. Available at: http://www.palgraveconnect.com/pc/doifinder/view/10.1057/9780230379657

Geda, S. (2008). Kasdienis gyvenimas poetui S. Gedai - pragariškas. [For poet S. Geda, everyday life is hellish life]. In Lietuvos rytas. 14 January. Available at: http://lietuvosdiena.Irytas. 1t/-12002886231200062208-kasdienis-gyvenimas-poetui-s-gedai-pragari\%C5\%A1kas.htm (accessed 18 April 2014)

Kantor, V. (2007). Russkii evropeec kak zadacha Rossii [The Russian European as the problem of Russia]. In Site de l'Institut europeen Est-Ouest. Available at: http://institut-est-ouest.ens-lyon.fr/spip. php?article138\&lang=en

Kantor, V.N. (2016). Myslima li Evropa bez Rossii? [Can Europe be imagined without Russia?], In Filologicheskie nauki [Journal of Philosophical Sciences]. Moscow, Humanist Publishing House, 3, 78-85.

Leerssen, J. (2007). Nation, ethnie, people, In Beller, M. \& Leerssen, J., eds. Imagology: The cultural construction and literary representation of national characters. A critical survey. AmsterdamNew, York, Rodopi, 377-381.

Lefebvre, V. (2002). Strategicheskie resheniia i moral' [Strategic decisions and moralyty]. In Refleksivnye processy i upravlenie [Reflexive processes and control], 2 (1), 24-26. Available at: http:// www.reflexion.ru/Library/Lefebvre_2002_1.htm

Levinas, E. (1994). Etika ir begalybe [Ethics and Infinity]. Transl. by A. Sverdiolas. Vilnius, Baltos lankos, $137 \mathrm{p}$.

Milosz, Cz. (1981). Native Realm: A Search for Self-Definition. Transl. by. C.S. Leach. University of California Press, Berkeley, LA, London. DOI: 10.3366/tal.2015.0195.

Nef, John U. (1958). Cultural Foundations of Industrial Civilization. New York, Cambridge University Press. 164 p. DOI: 10.1017/S0034670500022506

Plotnikov, N. (2008). Ot "individual'nosti” k "identichnosti” (istoriia poniatii personal"nosti v russkoi kul'ture). [From "individuality" to "identity" (the history of the concept of ,personality" in Russian culture]. In Novoe literaturnoe obozrenie, 91, 64-83. Available at: http://nlobooks.ru/sites/ default/files/old/nlobooks.ru/rus/magazines/nlo/196/954/959/index.html (accessed 20 May 2016).

Remizova, M. (2000). Vniz po lestnice, vedushchei vniz [Down the down staircase]. In Novyi Mir, 5, 190-193. Available at: http://magazines.russ.ru/novyi_mi/2000/5/remiz.html (accessed 20 May 2016).

Shishkin, M. (1998). Urok shveitsarskogo. [Swiss Lesson]. In Inostrannaia literatura, 9. Available at: http://magazines.russ.ru/inostran/1998/9/shishkin.html (accessed 20 May 2016). 
Shishkin, M. (2005). "Iazyk - eto oborona". Mikhail Shishkin o novom tipe romana, russkom iazyke i liubvi k Akakiiu Akakievichu. ["A language is a defence". Mikhail Shishkin describes a new type of novel, the Russian language and love to Akaky Akakievich]. An Interview with M. Shishkin by Gleb Morev. In Kriticheskaia massa, 2. Available at: http://magazines.russ.ru/km/2005/2/sh3.html (accessed 20 November 2016)

Shishkin, M. P. (2006). Spasennyi iazyk. [Saved language]. In Shishkin, M.P. Urok kalligrafii: roman, rasskazy [Calligraphy Lesson: the novel, stories]. Moscow, Vagrius. 345-350. Available at: http:// www.goneliterate.ru/comm/rezervo/event/607.xml (accessed: 10 May 2015).

Shishkin, M. (2010). “Grazhdanin Al’p”. [“An Alps Citizen”]. An Interview with M. Shishkin by E. Belzhelarskii. In Itogi, 40 (747), 4 October. Available at: http://www.itogi.ru/iskus/2010/40/157417. html (accessed 10 May 2015).

Shishkin, M. (2011). "Chelovek mozhet obmanyvat", a ego tekst - nikogda" [A man can deceive, but the textcan never deceive]. An Interview by J. Volodarskii. Portal o sovremennoikul 'ture «ShO» [Website about modern culture "ShO"] Available at: http://sho.kiev.ua/article/924?page $=002 \% 2 \mathrm{C} 0 \% 2 \mathrm{C} 43$ 01.09.2011(accessed 1 September 2015).

Shishkin, M. (2013a). Poets and Czars. From Pushkin to Putin: the sad tale of democracy in Russia Translated by J. Ioffe. In NEW REPUBLIC, 1 July. Available at: https://newrepublic.com/article/113386/ pushkin-putin-sad-tale-democracy-russia (accessed 1 September 2015).

Shishkin, M. (2013b). "Tol 'ko kogda vam zatknut rot, vy poimiote, chto takoe vozdukh" ["Only when they will shut your mouth, you will understand what the air means to you']. An Interview by N. Sikorskaia, 16 December. Available at: http://www.colta.ru/articles/_made/1544 (accessed 1 September 2015).

Shishkin, M., Akunin, B. (2013). "Chtob on provalilsia, vizantiiskii orel s dvumia golovami". Boris Akunin i Mikhail Shishkin sporiat o tom, obrechena li Rossiia (29 iiulya). ["Damn you, the Byzantine eagle with two heads". Boris Akunin and Mikhail Shishkin argue about whether Russia is doomed], 29 July. Available at: http:/gorod.afisha.ru/archive/akounin-vs-shishkin/ (accessed 1 September 2015).

Shishkin, M. (2014). "Dlia menia russkaia literatura - ogromnoe derevo". ["From my point of view, Russian literature is a great tree"], In ReadRate. 18 November. Available at: http://readrate. com/ rus/ratings/mikhail-shishkin-dlya-menya-russkayaliteratura-ogromnoe-derevo (accessed 19 November 2015).

Shishkin, M. (2015). 69 strof Il'my Rakuzy [69 strophes by Ilma Rakusa], In Colta.ru., 21 May. Available at: http://www.colta.ru/articles/swiss_made/7394 (accessed 1 September 2015).

Shishkin, M., Zhadan, S. (2015). Intellektual kak vrag naroda [Intellectual as an enemy of the people], In PEOPLE, 20 October. Available at: http://n-drizitskaya.com.ua/shishkin-zhadanintellektual-kak-vrag-naroda/ (accessed 14 December 2015).

Shishkin, M. (2016a). Mikhail Shishkin: "vse pisateli dolzhny poluchit" po Nobelevskoi premii”. [Mikhail Shishkin: "all writers have to receive the Nobel Prize"]. An Interview by E. Fomina, In RUS. POSTIMEES.EE (Estonia), 6 Juny. Available at: http://rus.postimees.ee/3719763/mihail-shishkin-vsepisateli-dolzhny-poluchit-po-nobelevskoy-premii (accessed 3 December 2016). 
Shishkin, M. (2016b). Mikhail Shishkin - Artemii Troitskii (conversation). 5/8, 10 December, In ERR Videoarhiiv. Available at: http://arhiiv.err.ee/guid/20160615025806401000300112290E2BA238B 440000000792B00000D0F20521(accessed 3 December 2016).

Sizemskaia, I.N. (2015). Rossiia i Evropa: V.V. Veidle o evropeiskikh tradiciiakh v russkoi kul'ture. [Russia and Europe. V.V. Veidle on the European Traditions in Russian culture], In Filosofiia i kul 'tura. [Philosophy and culture], 5, 704-714. DOI: 10.7256/1999-2793.2015.5.14802 PEOPLE 20 October.

Smith, A.D. (2009). Ethno-symbolism and Nationalism: A Cultural Approach. New York, Routledge, 192 p. DOI: 10.1017/S1537592710004019.

Struve, G. (1950). Russkii evropeec. Materialy dlia biografii $i$ kharakteristiki kniazia P.B. Kozlovskogo. [The Russian European. Materials for Prince P.B.. Kozlovsky's biography]. San Francisco, Delo Publishing Co, 164 p.

Tsymbursky, V.L. (1997). Rossiia v usloviiakh strategicheskoi nestabil'nosti. [Russia under the Conditions of Strategic Instability], In Lebed'. Nezavisimyi bostonskii al 'manakh. [Boston Independent Almanac Lebed] 27 August. Available at: http://lebed.com/1997/art176.htm (accessed 8 December 2016).

Uspensky, B.A. (2012). Europe as Metaphor and Metonymy (in Relation to the History of Russia), In "Tsar and God" and Other Essays in Russian Cultural Semiotics. Boston, Academic Studies Press, 175-190.

Venclova, T. (2004). Russkii evropeec [The Russian European], In Etkind, E. Zdes' i tam [Here and there]. St. Petersburg, Akademicheskij prospekt, 381-391.

Venclova, T. 2014. Tomas Venclova: nesu jau toks džentelmenas [I'm not such a gentleman], In Verslo žinios [Business news], 10 October. Available at: http://vz.lt/archive/article/2014/10/10/tomasvenclova-nesu-jau-toks-dzentelmenas (accessed 8 December 2016).

\section{Русский европеец: \\ случай Михаила Шишкина}

Г.П. Михайлова

Вильнюсский университет

Литва, LT-01513, Вильнюс, ул. Университетская, 3

Понятие и понимание «русского европейиа» связаны с определениями Европы как идеи и как идентичности. Представление о Европе как символе и кольбели духовных, этических и правовых ценностей присуще ментальности как России, так и Центральной и Восточной Европь. Поэтому есть возможность сравнить модели поведения и образ мысли, а также временные периоды кризиса самоидентификации эмигрировавших «европейцев» Шишкина и Чеслава Милоша, столкнувшихся с Западной Европой. Оберегая русскую начиональную идентичность, Шишкин, оказавшись в Швейцарии, обратился к дискурсивной позищии, которую можно обозначить как «наследие культурных форм», и написал литературно-исторический путеводитель и сборник эссе, посвященные русским «местам памяти» в Швейцарии. Что касается публицистики, то предлагаемый Шишкиным «рещепт» для перемен и возрождения России «Информачия. Просвещение. Смягчение нравов. Свободное слово»- достаточно традищионен 
для русских «западников». В статье подчеркивается, что в основе «рецепта» лежит философия диалогической природы человеческого бытия, тесно связанная с идеей свободы и с этикой диалогического персонализма, основанной на категориях ответственности, обязательств, симпатии и сострадания. Важно, что именно сострадание является нервом большой и малой прозы Шишкина. Утверждая диалогические отношения с западной иұивилизацией и культурой и убедившись в невозможности «диалога с государством», Шишкин, как некогда Набоков, выводит гражданское служение писателя за предель художественной прозы, но оставляет за собой право критической рефлексии и комментария в жанре публицистики. Очевидно желание Шишкина отождествить себя с космополитичной культурной элитой. Поэтому его суждения о «другой России» и своей принадлежности к ней подразумевают, прежде всего, культурную оппозищию; его позищия - это позищия индивидуального самоопределения художника, принцип гражданского партикуляризма, гармонично сочетающийся с космополитизмом и «умнымм национализмом».

Ключевые слова: Европейская идея, философия диалога, этические иенности, начиональная идентичность, самоидентификация.

Научная специальность: 10.00.00 - филологические науки. 